\title{
KEGAGALAN MEMUTUSKAN PEMENUHAN KEBUTUHAN NUTRISI SELAMA KEHAMILAN: STUDI GROUNDED THEORY PADA IBU HAMIL ANEMIA
}

\author{
Sabi'ah Khairi ${ }^{1,2 *}$, Setyowati ${ }^{3}$, Yati Afiyanti ${ }^{3}$ \\ 1. STIKes Yarsi Mataram, Mataram 83126, Indonesia \\ 2. Program Studi Magister, Fakultas Ilmu Keperawatan, Universitas Indonesia, Depok 16424, Indonesia \\ 3. Fakultas Ilmu Keperawatan, Universitas Indonesia, Depok 16424, Indonesia \\ *E-mail: sabiahkhairi@yahoo.com
}

\begin{abstract}
Abstrak
Salah satu penyebab anemia adalah kekurangan nutrisi. Kondisi anemia dalam kehamilan merupakan kondisi yang berisiko dan menjadi penyebab tidak langsung kematian ibu. Tujuan penelitian ini adalah mengembangkan konsep tentang proses pengambilan keputusan pemenuhan kebutuhan nutrisi ibu hamil anemia. Metode kualitatif dengan pendekatan grounded theory digunakan dengan 25 partisipan yang diperoleh melalui metode theoretical sampling di wilayah Kabupaten Lombok Timur, NTB. Melalui analisis data tematik diperoleh konsep kegagalan memutuskan dalam memenuhi kebutuhan nutrisi selama kehamilan. Pengambilan keputusan, baik oleh suami atau diri sendiri yang gagal memenuhi kebutuhan nutrisi dipengaruhi oleh berbagai faktor. Hasil penelitian ini menyarankan agar petugas kesehatan meningkatkan edukasi secara lebih intensif terkait nutrisi dan anemia dalam kehamilan, melibatkan partisipasi suami dan keluarga dalam edukasi dengan tetap memperhatikan aspek sosial budaya.
\end{abstract}

Kata kunci: grounded theory, ibu hamil anemia, nutrisi, pengambilan keputusan

\section{Abstract}

Failure in Deciding A Nutrition Requirement During Pregnancy: A Grounded Theory Study among Anemic Maternal Women. One of the causes of nutritional deficit is anemia. Anemia in pregnancy indirectly causes maternal mortality. This study aimed to develop a concept of decision-making in fulfilling the needs of nutrition in pregnant mothers with anemia. A grounded theory approach was applied involving 25 participants recruted through a theoretical method sampling in the East Lombok district. Through a thematic analys it was founded that there was a failure relating concept in decision making to meet nutrition requirement during pregnancy. There are several factors affect decisions made both by husbands and pregnant woman which were lead to failure. The finding recommends the care providers to improve health education regarding the importance of adequate nutrition for pregnant women and to involve husband and family during education proces while constantly respects social cultural aspects.

Keywords: decision-making, grounded theory, nutrition, pregnancy with anemia

\section{Pendahuluan}

Kematian ibu disebabkan oleh berbagai hal baik yang langsung maupun tidak langsung. Salah satu penyebab tidak langsung adalah anemia pada kehamilan (40\%), (Direktorat Bina Gizi Masyarakat, 2004; Depkes RI, 2010). Anemia merupakan salah satu kelainan hematologi yang sering terjadi pada kehamilan. Anemia pada ibu hamil mayoritas disebabkan oleh defisiensi zat besi. Kondisi ini mempengaruhi sekitar $15-25 \%$ ibu hamil dan berkontribusi sebesar $40 \%$ sebagai penyebab kematian ibu dan kelahiran prematur.
Provinsi Nusa Tenggara Barat (NTB) menempati urutan kedua Angka Kematian Bayi (AKB) tertinggi di Indonesia, yaitu 72 per 1000 kelahiran hidup menurut SDKI tahun 2007 (Depkes RI, 2009). Sementara itu, Angka Kematian Ibu (AKI) 94 per 100.000 kelahiran hidup, dengan prevalensi kejadian anemia pada ibu hamil tahun 2002 mencapai 77,01\% (Dinkes Provinsi NTB, 2008; Dinkes Provinsi NTB; 2009).

Anemia pada ibu hamil diperkirakan muncul karena model penanggulangan yang bersifat kuratif, misalnya pemberian makanan tambahan 
(PMT) dan pemberian tablet besi tanpa mempertimbangkan karakteristik penduduk dengan beragam situasi demografi dan sosial budaya yang melekat (Zuluchu, 2007). Keberagaman situasi demografi dan sosial budaya di Indonesia berkontribusi terhadap rendahnya kesadaran masyarakat tentang pentingnya nutrisi bagi ibu hamil. Faktor yang mempengaruhi rendahnya kesadaran tersebut diantaranya adalah latar belakang pendidikan, sosial ekonomi keluarga, kebijakan, serta lingkungan masyarakat dan politik. Selain itu, masalah ketidaksetaraan gender, nilai budaya, serta kurangnya dukungan dari petugas kesehatan merupakan faktor yang mempengaruhi ibu hamil untuk memilih dan memutuskan upaya meningkatkan kesehatan reproduksi termasuk kebutuhan nutrisi (Begley, 2002; Chakraborty \& Anderson, 2011; Juliastuty, Setyowati, \& Afiyanti, 2008; Setyowati, 2003; Shannon, Mahmud, Asfia, dan Ali, 2008; \& Zuluchu, 2007).

Tujuan penelitian ini adalah mengembangkan konsep dengan mengeksplorasi lebih jauh pada interaksi sosial ibu hamil anemia dalam mengambil keputusan terhadap pemenuhan kebutuhan nutrisi.

\section{Metode}

Penelitian ini menggunakan pendekatan grounded theory. Konsep yang menjadi hasil penelitian ini didasarkan atas realitas yang ditemukan di lapangan, yang dikenal dengan symbolic interacttionalism (Poerwandari, 2009; Strauss \& Corbin, 2009).

Partisipan dipilih dengan theoretical sampling. Data diperoleh melalui wawancara pada $15 \mathrm{ibu}$ hamil anemia, lalu pemuka masyarakat, dukun, petugas kesehatan, dan tetangga sekitar.

\section{Hasil}

Kategori inti yang diperoleh adalah "kegagalan memutuskan pemenuhan kebutuhan nutrisi selama kehamilan". Konsep yang membentuk kategori inti tersebut, meliputi:
Faktor Budaya sebagai Penghambat Asupan Nutrisi Adekuat. Pengaruh kuat dari budaya berpantang makanan membatasi partisipan dalam mencukupi kebutuhan nutrisi terutama asupan protein hewani.

"Kan kata orang Sasak itu kalau hamil kita nggak boleh makan cumi, nggak boleh makan udang katanya...makanya kita takut beli...itu katanya orang-orang tua ndak boleh kalau hamil katanya." (P3)

Keyakinan terhadap budaya berpantang makanan juga diperkuat oleh adanya pengalaman persalinan memanjang baik sebagai pengalaman pribadi maupun orang lain.

"Yakin saya...(dengan suara keras sambil menganggukkan kepala) itu sebabnya saya ndak berani makan udang sampai sekarang..." (P1)

Kebiasaan makan masyarakat suku Sasak adalah mengkonsumsi lauk seadanya. Hal ini juga terlihat dari pemikiran yang tidak mementingkan kandungan gizi dalam makanan sehari-hari.

"kalau makan mungkin karena selera, dari diri sendiri... saya juga tidak terlalu memikirkan untuk kandungan, dan yang lebih megenyangkan adalah nasi dan sayur, termasuk kebiasaan orang sini juga... pokoknya terisi perut dan kenyang." (P5)

Faktor lain yang sangat mempengaruhi partisipan adalah adanya pola pikir masyarakat suku Sasak yang kurang mendukung terhadap kesehatan terutama dalam memenuhi kebutuhan nutrisi termasuk saat hamil. Harta atau uang yang dimiliki bukan digunakan untuk membeli makanan, melainkan untuk membeli perhiasan, tanah, keperluan acara kenduri atau hal-hal yang bisa dilihat oleh orang lain.

\section{Kurang Pengetahuan dan Paparan Informasi Terkait Kebutuhan Nutrisi Ibu Hamil.} Separuh partisipan ibu hamil mengetahui jenis makanan yang baik untuk kehamilan seperti sayur, ikan daging, buah serta susu. Akan tetapi semua partisipan tidak mengetahui kebutuhan nutrisi selama kehamilan seperti porsi harian dan kandungan gizi tiap jenis makanan. 
"Ndak tahu saya (sambil tertawa)...Yaaa... anu...apa namanya itu, lauk-lauk yang biasa. Sama seperti yang sebelum hamil itu kan. Sama saja. Ya seperti daun ketujur ya pokoknya sama saja, bukan berarti pas hamil itu harus makan yang enak-enak, tapi ya sama saja makanannya kan." (P1)

Ketidaktahuan tentang kegunaan nutrisi ini dipengaruhi oleh rendahnya tingkat pendidikan.

"Kebanyakan memang dari faktor ketidaktahuannya tentang gizi itu. Kan begini... rata-rata yang kawin di pedusunan ini adalah mereka yang kawin di bawah sekolah standar, di bawah sekolah 9 tahun. Artinya wajar 9 tahun ini kan sampai tamat SMP...trus rata-rata pendidikan sampai SD mentok ndak melanjutkan sampai wajar 9 tahun itu. Sehingga pengetahuan sampai SD itu apa sih yang mereka tahu..." (P16)

Edukasi tentang kebutuhan gizi harian oleh petugas kesehatan yang kurang membuat partisipan tidak memahami akan pentingnya nutrisi selama kehamilan. Delapan dari $15 \mathrm{ibu}$ hamil mengaku tidak pernah dijelaskan oleh petugas kesehatan tentang kandungan gizi dalam makanan, hanya mendapatkan anjuran untuk makan banyak.

\section{Kurang Dukungan Keluarga dalam Mencu-} kupi Nutrisi selama Kehamilan. Keluarga, dalam meningkatkan kesehatan kehamilan berperan memberi anjuran makan banyak, istirahat yang cukup serta larangan untuk beraktivitas terlalu berat seperti ke sawah. Namun demikian, suami dan keluarga tidak pernah menganjurkan jenis makanan yang harus dikonsumsi karena faktor ketidaktahuan.

"Ya kita suruh sih dia makan banyakbanyak sering-sering hehehe...tapi ndak bisa kita mendukung jenis makanan yang bergizilah istilahnya. Karena nggak tahu kita mana yang baik dan yang jelek itu orang hamil itu kan. Jadinya apa-apa yang ada sudah yang dimakan." (Suami P1)

Berpantang makanan dalam budaya Sasak juga mempengaruhi orang tua dan suami.
"Gini dia (orang tua) bilang ndak boleh makan cumi, kepiting, udang, sama gurita juga ndak boleh, kalau beli kan kadangkadang suami kepengen ndak sih saya makan ndak boleh katanya...Disini semua orang bilang seperti itu." (P11)

Ketidakmampuan Menyediakan Nutrisi Adekuat selama Kehamilan. Sebagian besar penduduk di Kecamatan Sakra berada pada tingkat ekonomi lemah atau keluarga miskin (keluarga pra sejahtera dan sejahtera 1). Hal ini juga terlihat dari karakteristik keluarga partisipan ibu hamil, yaitu sembilan partisipan sumber penghasilannya dari buruh tani berupah harian, dua Partisipan berpenghasilan tetap setiap bulan namun di bawah upah minimum, dua Partisipan bekerja sebagai berjualan sayur dan makanan ringan, dan dua orang petani tembakau yang memiliki lahan sawah.

Keterbatasan penghasilan yang juga tergantung pada cuaca atau musim terkadang memaksa mereka untuk tetap bekerja walaupun dalam kondisi hamil.

"Walaupun pergi memburuh kebanyakan untuk anak belanja bisa sampai 7.000-8.000 habis sehari, lain lagi untuk kebutuhan sehari-hari didapur...tapi kan anak kita banyak untuk belanja...nanti kan anak kita nangis kalau tidak ada uang, gimana rasanya kalau dia nangis pengen beli jajan.itu juga yg saya pikirkan...” (P13)

Upah harian sebagai penghasilan utama membuat lemah daya beli partisipan terutama untuk makanan seperti ikan, ayam, daging dan susu. Hal ini yang membuat konsumsi makanan dari hewani tidak bisa setiap hari.

\section{Proses Pengambilan Keputusan Pemilihan} Makanan didalam Keluarga. Dua partisipan ibu hamil menyatakan bahwa kebutuhan dan jenis makanan sehari-hari ditentukan oleh keluarga. Hal ini diperkuat dengan pengaruh budaya Sasak terkait pantangan makanan. Sebagian besar masyarakat berpegang teguh pada tradisi turun temurun tersebut. Hal ini terlihat dengan dominasi keluarga (orang tua, mertua, atau 
suami) dalam menentukan makanan boleh dikonsumsi atau tidak seperti makanan laut. Sembilan partisipan ibu hamil harus mengikuti larangan tersebut.

"Ndak boleh orang tua bilang, besok kalau gak nurut jangan terlalu kekeh biar kamu selamat katanya, makanya kita patuhi, apalagi gurita itu jangan makan biar nggak keluar masuk anaknya nanti, akhirnya takut kita jadinya...Suami juga bilang seperti itu, ndak boleh kitanggak nurut sama kata orangtua, nanti kwalat katanya." (P11)
Dalam penelitian ini, hanya sepertiga partisipan ibu hamil dapat menentukan sendiri apa yang dimakan sehari-hari.

Kegagalan memutuskan pemenuhan kebutuhan nutrisi dapat terjadi karena kecenderungan membiarkan apa yang terjadi dalam kehidupannya termasuk anggapan bahwa kehamilan adalah suatu hal yang biasa. Hal ini membuat partisipan tidak memikirkan kondisi kesehatannya termasuk makanan yang dibutuhkan dan tidak berusaha mencari informasi.
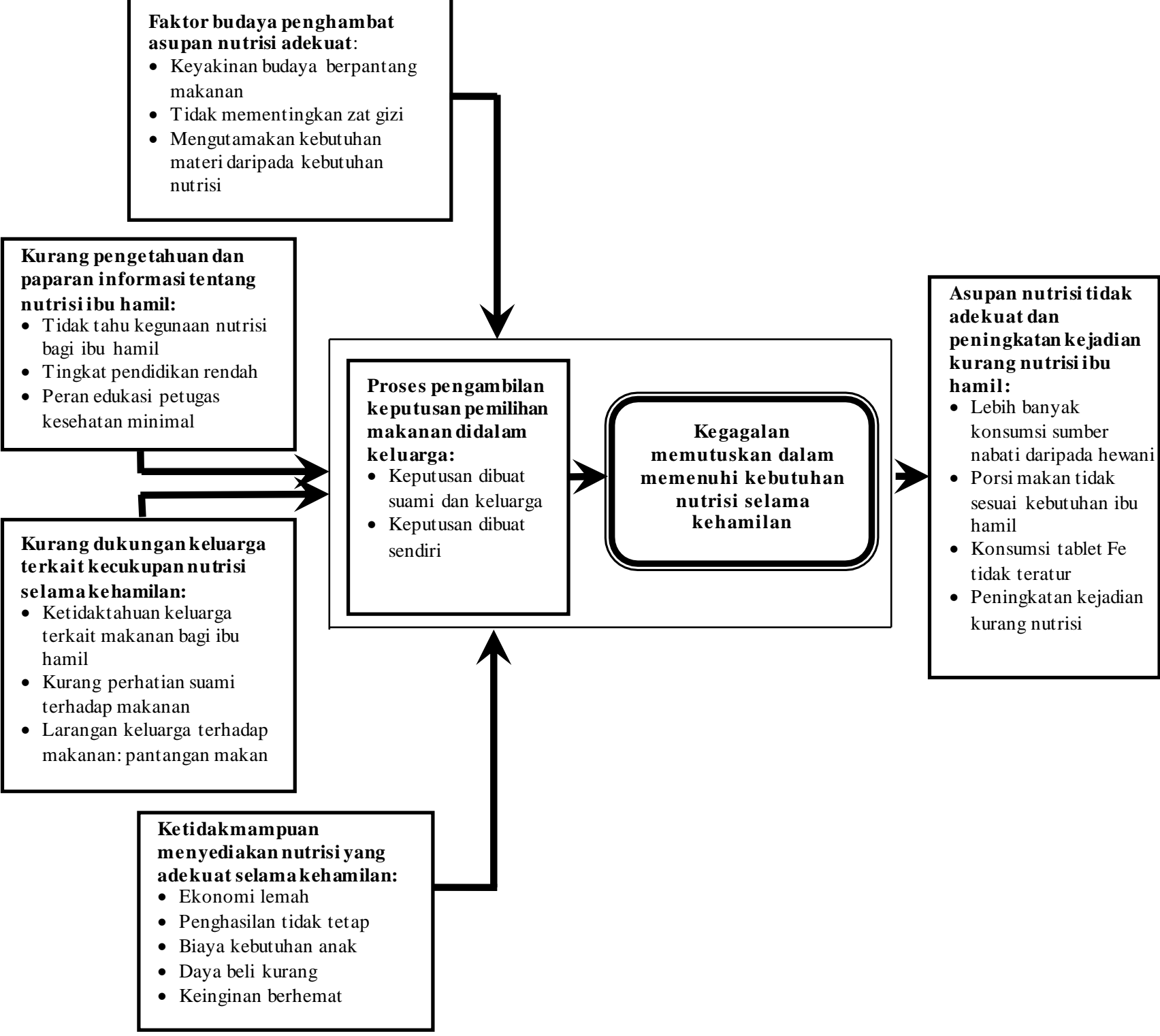

Gambar 1. Kerangka Model Teoritis Grounded Theory "Pengambilan Keputusan Pemenuhan Kebutuhan Nutrisi Ibu Hamil Anemia" 
"Nggak pernah kita tanya-tanya, yang penting sehat sudah...biasa-biasa aja kalau hamil itu jak ...apa yang ada itu yang dimakan ...yang penting ada isi perut." (P1)

\section{Asupan Nutrisi Tidak Adekuat dan Pening- katan Kejadian Kurang Nutrisi Ibu Hamil.} Sehari-hari ibu hamil lebih banyak mengonsumsi sumber nabati seperti sayuran dan tahu, tempe dibanding hewani. Sementara itu sumber hewani yang sering dikonsumsi adalah dari telur yang berdaya serap zat besi rendah. Jenis makanan dengan daya serap zat besi tinggi seperti ikan, ayam dan daging jarang dikonsumsi.

“...Sehari-hari saya senang makan sayuran seperti bayam, ter-teri juga, daun ketujur. Pokoknya yang anu inilah...yang hijau-hijau suka petik-petik di sawah seperti komak, antap gitu...kalau ikan cuma dua kali seminggu." (P1)

Tujuh partisipan ibu hamil tidak rutin mengkonsumsi tablet besi karena efek mual dan muntah. Hal ini juga menjadi kontributor terjadinya anemia dan kurang energi kronis selama kehamilan.

Beberapa penemuan ini membentuk konsep utama (Gambar 1), yaitu: 'kegagalan memutuskan dalam pemenuhan kebutuhan nutrisi selama kehamilan".

\section{Pembahasan}

Pengaruh adat, kebiasaan dan budaya suku Sasak merupakan faktor utama yang mendasari kegagalan dalam memutuskan pemenuhan kebutuhan nutrisi selama kehamilan. Ibu hamil suku Sasak dilarang mengonsumsi gurita, cumi, udang, ikan pari, dan ikan keluyu. Jenis makanan ini diyakini dapat menyebabkan bayi ataupun plasenta sulit keluar saat melahirkan. Hampir seluruh partisipan merasa takut jika melanggar aturan yang turun temurun tersebut. Hal ini sejalan dengan pendapat Swasono (1998), yaitu adat memantang makanan telah diajarkan secara turun temurun dan cenderung ditaati walaupun individu yang menjalankan tidak terlalu yakin alasannya.
Pantangan makanan yang sebagian besar berasal dari sumber hewani berdampak pada tingginya angka kekurangan nutrisi ibu hamil khususnya anemia. Fenomena ini juga terlihat pada kebiasaan mengkonsumsi lebih banyak sumber nabati dibanding hewani yang berakibat pada kekurangan asupan makanan yang mengandung zat besi, protein, vitamin dan zat gizi penting lainnya.

Misterianingtyas, Asmaningsih, dan Pudjirahadju (2006) menyatakan bahwa kandungan zat besi yang berasal dari sumber nabati (non heme) merupakan bahan makanan yang berdaya absorbsi zat besi rendah. Seperti jenis sayuran bayam hanya berdaya serap zat besi sebesar $1 \%$. Protein nabati yang berasal dari kedelai juga hanya berdaya serap zat besi sebesar $6 \%$. Sementara itu telur hanya berdaya serap zat besi sebesar 2-6\% (Misterianingtyas, Asmaningsih, dan Pudjirahadju, 2006).

Hal menarik yang ditemukan adalah adanya pola pikir masyarakat suku Sasak yang kurang memperhatikan pemenuhan kebutuhan gizi keluarga. Masyarakat lebih tertarik menginvestasikan harta untuk kebutuhan materi dibanding untuk memenuhi kebutuhan makan. Fenomena ini sesuai dengan yang disampaikan oleh Marquis dan Huston (2003/2010), bahwa dalam mengambil keputusan, manusia dipengaruhi oleh bias individu yang muncul dari perbedaan nilai, pengalaman hidup, serta pilihan individu dan keinginan individu untuk mengambil risiko.

Kegagalan memenuhi kebutuhan nutrisi juga dipicu oleh kurangnya pengetahuan tentang kebutuhan dan manfaat zat gizi dalam makanan. Pemahaman ini merupakan dasar dalam menentukan pilihan makanan yang sehari-hari. Hal ini sesuai temuan Mawaddah dan Hardiansyah (2008) yaitu pengetahuan tentang gizi akan menentukan atau membentuk perilaku.

Rendahnya pengetahuan tentang nutrisi ini dapat terjadi karena masyarakat belum mendapatkan edukasi yang memadai. Hal ini sesuai dengan studi Begley (2002) yang menyatakan bahwa ada dua hambatan wanita untuk mendapatkan asupan nutrisi yang baik selama kehamilan, 
yaitu; (1) kurangnya pengetahuan dan nasehat terkait asupan nutrisi yang baik untuk kehamilan, dan (2) kurangnya edukasi tentang nutrisi kehamilan oleh petugas kesehatan.

Dukungan keluarga merupakan faktor penting yang mempengaruhi asupan nutrisi pada ibu hamil. Sebagian besar partisipan kurang mendapat dukungan dari suami dan keluarga lainnya dalam memenuhi kebutuhan gizi selama kehamilan. Hal ini sesuai dengan studi Shannon, Mahmud, Asfia, dan Ali (2008) di Bangladesh yang menemukan salah satu faktor penghambat ibu hamil dalam meningkatkan asupan nutrisi yaitu kurangnya dukungan atau kepedulian keluarga pada asupan nutrisi ibu hamil.

Faktor ketidakmampuan memang menjadi faktor utama yang menghambat partisipan untuk memilih dan memutuskan memenuhi kebutuhan nutrisi. Hal ini sesuai studi Hartini, dkk. (2003) yang menemukan bahwa wanita berstatus sosial rendah di dalam masyarakat khususnya berekonomi lemah berisiko nutrisinya tidak terpenuhi selama kehamilan. Studi yang dilakukan oleh Ugwuja, Akubugwo, Ibiam, dan Obidoa (2011) pada wanita hamil di Nigeria menemukan hubungan signifikan antara kejadian anemia, malaria, dan ISPA dalam kehamilan terhadap status sosial ekonomi wanita hamil yang bekerja sebagai petani, tidak sekolah, dan tinggal sendiri.

Faktor-faktor seperti yang telah dijelaskan akan mempengaruhi ibu hamil anemia dalam proses mengambil keputusan pada pemilihan makanan untuk keluarga. Hasil penelitian memperlihatkan bahwa pengambilan keputusan dalam menentukan kebutuhan makan lebih dominan dilakukan oleh keluarga yaitu suami, orang tua, atau mertua walaupun ada juga yang dilakukan karena keinginan sendiri. Studi etnografi Setyowati (2003) menemukan bahwa keluarga dan komunitas juga berpengaruh terhadap keputusan wanita dalam memenuhi kebutuhan nutrisi selama hamil.

Beberapa faktor tersebut saling berhubungan dan mempengaruhi sehingga muncul kecen- derungan untuk membiarkan apa yang terjadi dalam kehidupannya karena beranggapan bahwa kehamilan adalah hal yang biasa. Kondisi ini membuat tidak adanya keistimewaan terhadap pemeliharaan kesehatan, tidak berusaha bertanya atau mencari informasi, dan pembicaraan tentang kebutuhan nutrisi selama kehamilan. Partisipan menerima saja kondisi yang ada termasuk konsumsi makanan seharihari tanpa pertimbangan khusus.

Friedman (2003) menyatakan bahwa keluarga dapat mengambil keputusan dengan menggunakan cara de-facto, yakni sesuatu dibiarkan terjadi tanpa perencanaan sebelumnya. Keputusan dilakukan pada kondisi tidak ada pembuat keputusan yang aktif, kesukarelaan dan efektif. Kondisi ini salah satunya dapat dipicu pengetahuan dan norma budaya yang dapat menghambat seseorang atau keluarga melakukan komunikasi terbuka dan pembuatan keputusan aktif.

\section{Kesimpulan}

Proses pengambilan keputusan dalampemenuhan kebutuhan nutrisi ibu hamil anemia dan pemilihan makanan dalam keluarga sangat dipengaruhi oleh beberapa faktor utama yang meliputi: budaya penghambat asupan nutrisi adekuat, kurang pengetahuan dan paparan informasi tentang nutrisi ibu hamil, kurang dukungan keluarga, serta ketidakmampuan memenuhi nutrisi yang adekuat selama kehamilan. Fenomena ini memunculkan kategori inti yaitu "Kegagalan memutuskan pemenuhan kebutuhan nutrisi selama kehamilan" yang berdampak pada kurangnya asupan nutrisi hingga peningkatan kejadian kurang gizi pada ibu hamil.

Program edukasi yang intensif dan komprehensif oleh tenaga kesehatan sangat diperlukan bukan hanya sebatas anjuran meningkatkan asupan makan saja melainkan lebih menekankan pada komposisi makanan, kegunaan nutrisi, porsi harian serta pengetahuan tentang anemia dan dampaknya bagi kesehatan kehamilan. Selain itu perlu melibatkan partispasi keluarga dengan tetap menghormati aspek budaya (AT, INR). 


\section{Ucapan Terima Kasih}

Kepada berbagai pihak yang mendukung terealisasinya kegiatan penelitian ini, yaitu seluruh partisipan dan pihak Puskesmas Sakra, Dinas Kesehatan Kabupaten Lombok Timur NTB.

\section{Referensi}

Begley, A. (2002). Barriers to good nutrient intakes during pregnancy: A qualitative analysis. Nutrition \& Dietetics, 59 (3), 175180.

Chakraborty, P., \& Anderson, A. K. (2011). Maternal autonomy and low birth weight in India. Journal of Women's Health (15409996), 20 (9), 1373-1382.

Depkes RI. (2009). Profil kesehatan Indonesia 2008. Jakarta: Departemen Kesehatan RI.

Depkes RI. (2010). Laporan Riset Kesehatan Dasar (RISKESDAS) 2010. Jakarta: Departemen Kesehatan RI.

Dinkes Kabupaten Lombok Timur. (2009). Profil kesehatan Kabupaten Lombok Lombok Timur 2008. Selong: Dinas Kesehatan Kabupaten Lombok Timur.

Dinkes Provinsi NTB. (2008). Profil kesehatan NTB 2008. Mataram: Dinas Kesehatan Provinsi NTB.

Direktorat Bina Gizi Masyarakat. (2004). Pedoman uтит gizi seimbang (Edisi revisi). Jakarta: Departemen Kesehatan RI.

Friedman, M.M. (2003). Family nursing: Nursing theory and practice (3th Ed.). New Jersey Prentia Hall.

Hartini, T.N.S., Winkvist, A., Lindholm, L., Stenlund, H., Persson, V., Nurdiati, D.S., \& Surjono, A. (2003). Nutrient intake and iron status of urban poor and rural poor without access to rice fields are affected by the emerging economic crisis: The case of pregnant Indonesian women. European Journal of Clinical Nutrition, 57 (5), 654 666.
Juliastuty, D., Setyowati, \& Afiyanti, Y. (2008). Pengambilan keputusan pemakaian kontrasepsi pada ibu grande multipara di Kabupaten Tangerang: Study grounded theory. Jurnal Keperawatan Indonesia, 12 (2), 100-107.

Marquis, B.L., \& Huston. C.J. (2010). Kepemimpinan dan menejemen keperawatan teori dan aplikasi (Edisi 4) (Widyawati, W Handayani, \& F. Ariani, penerj). Jakarta: EGC. (Buku asli diterbitkan 2003).

Mawaddah, N., \& Hardiansyah. (2008). Pengetahuan, sikap, dan praktek gizi serta tingkat konsumsi ibu hamil di Kelurahan Keramat Jati dan Kelurahan Ragunan Provinsi DKI Jakarta. Jurnal Gizi dan Pangan, 3(1), 30-42.

Misterianingtyas, W., Asmaningsuh, E., \& Pudjirahadju, A. (2006). Hubungan tingkat konsumsi energi dan zat gizi dengan kejadian Anemia pada ibu hamil trimester III Desa Jatiguwi, Kecamatan Sumber Pucung, Kabupaten Malang (Tesis, Program Pascasarjana). Program Pascasarjana Universitas Brawijaya, Malang. Diperoleh dari http:// elibrary.ub.ac.id/.

Poerwandari, E.K. (2009). Pendekatan kualitatif untuk penelitian perilaku manusia. Depok: LPSP3.

Setyowati. (2003). The impact of village midwives and cadres in improving the nutritional of pregnant women in selected rural villages in two districts, Banten Province Indonesia 2003: A longitudinal descriptive study (Dissertation). Diperoleh dari http://epress. lib.uts.edu.au/dspace/bitstream/handle/2100/266/ 01front.pdf?sequence $=1$.

Shannon, K., Mahmud, Z., Asfia, A., \& Ali, M. (2008). The social and environmental factors underlying maternal malnutrition in rural Bangladesh: Implications for reproductive health and nutrition programs. Health Care for Women International, 29 (8/9), 826-840.

Strauss, A., \& Corbin, J. (2009). Dasar-dasar penelitian kualitatif tatalangkah dan teknikteknik teoritisasi data. (M. Shodiq \& I. Muttaqin, penerj). Yogyakarta: Pustaka Pelajar. Buku asli diterbitkan 1988. 
Swasono, M.F. (1998). Kehamilan, kelahiran, perawatan ibu dan bayi dalam konteks budaya. Jakarta: UI-Press.

Ugwuja, E.I., Akubugwo, E.I., Ibiam, U.A., \& Obidoa, O. (2011). Maternal socio demographic parameters: Impact on trace element status and pregnancy outcomes in
Nigerian women. J Health Popul Nutr, 29 (2), 156-162.

Zuluchu, F. (2007). Faktor sosio-psikologi masyarakat yang berhubungan dengan anemia ibu hamil di kota Tanjung Balai Sumatra Utara. Medan: Badan Penelitian dan Pengembangan Provinsi Sumatra Utara. 